\title{
The state and the perspectives of the eco-energy infrastructure development in Biała Podlaska County (Poland). Part II Estimation of solid biomass resources for energy purposes
}

\author{
Alina Kowalczyk-Juśko, ${ }^{1,}$, Agnieszka Listosz ${ }^{I}$, Klaudia Mazur ${ }^{l}$, Michał Maciagg ${ }^{I}$, Patrycja Pochwatka ${ }^{l}$, Andrzej Mazur $^{l}$ \\ ${ }^{1}$ University of Life Sciences in Lublin, Department of Environmental Engineering and Geodesy, Leszczyńskiego St. 7, \\ 20-069, Poland
}

\begin{abstract}
The paper estimates the possibility of obtaining solid biomass for energy purposes in the Biała Podlaska County (Lublin Voivodeship, Poland). The estimates were based on data on: forest area, orchards and tree stands, land use, crop structure, animal population, and marginal land area in the County. It was found that in most communes, there are great possibilities of obtaining biomass for energy purposes. The largest resource is straw $(243,501 \mathrm{Mg}$ per year), which should first be used in agriculture as animal litter and organic fertilizer. Only its surplus can be intended for the combustion and production of pellets and briquettes. In the County, large areas of poor quality land were inventoried, on which perennial energy plants with low requirements can be grown. Up to 113,595 Mg of biomass can be obtained there. The basic condition for the development of targeted energy crops is the emergence of a biomass market: installations that convert biomass into fuels or produce energy on a local scale and sell it to power plants. Currently, a commonly used resource is wood biomass from forests and wood processing, which is used as fuel in domestic boilers, as well as for the production of pellets and briquettes.
\end{abstract}

\section{Introduction}

Solid biomass is currently the dominant component of the Polish energy matrix [1]. Its importance results on the one hand from large resources, compared to other Renewable Energy Sources (RES), on the other hand, from the possibility of using it on a different scale: from wood-fired home boilers with a few $\mathrm{kW}$ to specialized boilers in power plants, including boilers with fluidized bed fed with ground biomass of several dozen MW. Besides, wood biomass from forests, which account for about $30 \%$ of the area in Poland [1], is mostly in the hands of the state institution: State Forest National Forests Holding, which facilitates trading in raw materials.

Poland's biomass market is not well organized, which is not conducive to the establishment of energy plantations. The hopes that were placed in the development of the energetic use of biomass at the beginning of the 21st century have largely failed [2]. Farmers do not decide on the cultivation of energy crops like perennial species without the guarantee of collecting raw material. On the other hand, power plants and combined heat power plants do not conclude contracts with small biomass producers. In this situation, the needs of energy producers are met by importing biomass, especially from agriculture (so-called agro-biomass) [3]. This is unfavorable due to environmental pollution caused by transport, as well as preventing the implementation of one of the essential aspects of renewable energy: the revival of the national economy, the creation of jobs, and new markets for the sale of agricultural produce. Meanwhile, local biomass resources are plentiful and diverse: wood biomass from forests, orchards and woodlots, straw and hay, whose surpluses are recorded in forestry and agriculture [4-6]. In the situation of a real increase in demand for domestic biomass, it is also possible to increase its supply by establishing energy plantations. Especially, perennial plants, whose biomass has a high calorific value, and the requirements allow for cultivation on low-quality land [7]. The last factor is becoming more and more relevant because the strategic documents of the European Union shape energy policy in such a way as to prevent conflicts between food production and agro-energetics [8]. The primary function of agriculture is food production. In contrast, energy production (in various conversion processes) should be limited to by-products, waste, and crops grown on land unsuitable for food and feed plants $[9,10]$.

The study aimed to assess local solid biomass resources, both currently available and obtainable in the near future, in a selected County with a typically agricultural character. The quantity and energy value of wood biomass from various sources (forests, wood processing, orchards, woodlots), straw and hay, as well as plants that could hypothetically be cultivated on lowquality lands, were estimated. 


\section{Materials and methods}

The article is part of the research carried out in the Biała Podlaska County (Lublin Voivodeship, Poland), the results of which, including the characteristics of the area and the diagnosis of the state of infrastructure producing energy from renewable sources, were published in the article Listosz et al. [11]. This article covers the analysis of solid biomass resources that are useful for use for energy purposes directly after harvesting (such as fireplace wood) or after initial processing into bales, pellets or briquettes. For each biomass (wood, straw, hay), the use for non-energy purposes (agricultural, industrial, food, feed) was first assumed. Surplus biomass can be treated as a potential energy resource. Methods of estimating energy biomass resources were used, described by Kowalczyk-Juśko [12]. After estimating the amount of biomass from each source, its energy value was determined. The following calorific values for biomass in working conditions were adopted: wood from forests, orchards and tree stands $-8.1 \mathrm{MJ} \cdot \mathrm{kg}^{-}$ ${ }^{1}$, wood waste from processing $-11.3 \mathrm{MJ} \cdot \mathrm{kg}^{-1}$, straw and hay $-13.9 \mathrm{MJ} \cdot \mathrm{kg}^{-1}$, biomass from special purpose crops $-14.1 \mathrm{MJ} \cdot \mathrm{kg}^{-1}$. These values are averaged results from own research as well as numerous literature. Estimates were carried out at each Commune level, and the results were added for the County.

Source data came from Local Data Bank [1], Agency for Restructuring and Modernization of Agriculture, Biała Podlaska County Authority Office, and 17 offices of rural communes and 2 municipal offices, which are part of this county. These data included: forest area, timber harvesting, tree growth, orchard area, length of roads, crop structure, cereal yields, animal population, soil complexes, the share of unused meadows.

\subsection{Identification of marginal soils for energy crops}

It is not advisable to allocate good quality land for energy purposes, which should be the basis for food and feed production. Soils for agricultural use complexes 5 , $6,8,9$, and $3 z$ are most useful for growing energy crops. The analysis was carried out based on soil complexes as indicators of soil quality assessment. The balance sheet includes restrictions resulting from organizational and logistic conditions. Therefore it was assumed to use $10 \%$ of the calculated area of marginal land to cultivate perennial plants for the production of solid biomass. In 3 communes, over $30 \%$ of the commune area is covered by various forms of nature protection, this percentage was reduced to $5 \%$. It was calculated that in the Biała Podlaska County, at least 12,211 ha of perennial energy crops can be allocated.

\subsection{Land use structure}

Agricultural land (67.1\%) dominates in the land use structure of the analyzed county and includes: arable land $(66.6 \%)$, meadows $(20.1 \%)$, pastures $(7.9 \%)$, and orchards $(1.4 \%)$. Due to the county's agricultural nature, the basic energy raw material could be by-products formed in agriculture and the agri-food industry, as well as biomass from special-purpose crops. However, the low utilization of biomass resources from agriculture means that in practice, wood biomass, mainly derived from forests, which constitute $27.4 \%$ of the county area, is more important.

\section{Results}

\subsection{Estimation of wood biomass resources}

\subsubsection{Forest biomass resources}

Wood from forests and the industrial processing this raw material is currently the most important source of biomass used in boiler rooms of individual houses as well as in combustion and co-combustion processes in power plants and combined heat power plants. The resources of this raw material are limited because, in Poland, rational and sustainable forest management has been conducted for many years, allowing the use of forest resources while maintaining the sustainability of forests and leading to an increase in the forest cover of the country. Uncontrolled logging from forests can have negative effects on complex, multi-species forest ecosystems [13].

Forest biomass resources, which can be used for energy purposes in the Biała Podlaska County, amount to almost $35,000 \mathrm{Mg}$, which is the equivalent of over 282,000 GJ per year (Table 1). The following municipalities have a significant share in the biomass resources of the county: rural Biała Podlaska (12.4\% of the total forest biomass resources), Drelów (11.6\%), and the rural commune of Międzyrzec Podlaski (9.7\%). The municipalities of Terespol (17 $\mathrm{Mg}$ per year) and Międzyrzec Podlaski (85 Mg per year) have a low technical potential of wood biomass from forests, which results from their low afforestation.

\subsubsection{Waste wood resources from wood processing}

Significant resources of waste wood arise during the processing of raw material in wood processing and processing plants. These are sawmills, woodworking craft factories, furniture industry plants (production of panels and furniture), paper and pulp industry factories. There are 26 wood processing plants in the county [11]. Wood waste resources were assessed based on the volume of timber harvested from the state and private forests located in the Biała Podlaska County. It was assumed that wood waste (sawdust, sawdust, chippings, chips, etc.) constitutes on average $20 \%$ of the initial mass intended for processing $[14,15]$.

The analysis showed that the estimated amount of wood waste that can be obtained annually in the Biała Podlaska county is about $12,000 \mathrm{Mg}$ (Table 1). The energy value of this waste is over 142,000 GJ. The limitation in using these resources is that a significant part of the waste generated during the processing of 
Table 1. Technical and energy potential of biomass from various sources in the communes of the Biała Podlaska County

\begin{tabular}{|c|c|c|c|c|c|c|c|}
\hline \multirow[b]{2}{*}{$\begin{array}{l}\text { Territorial Unit } \\
\text { (commune) }\end{array}$} & \multirow[b]{2}{*}{ Unit } & \multicolumn{3}{|c|}{ Wood } & \multirow[b]{2}{*}{ Straw } & \multirow[b]{2}{*}{ Hay } & \multirow{2}{*}{$\begin{array}{c}\text { Special } \\
\text { purpose } \\
\text { crops }\end{array}$} \\
\hline & & forest & $\begin{array}{c}\text { wood } \\
\text { processing }\end{array}$ & $\begin{array}{c}\text { orchads and } \\
\text { trees }\end{array}$ & & & \\
\hline \multirow{2}{*}{ Międzyrzec Podlaski* } & $\mathrm{Mg}$ & 85 & 31 & 18 & 1961 & 130 & 0 \\
\hline & GJ & 689 & 350 & 146 & 27258 & 1807 & 0 \\
\hline \multirow{2}{*}{ Terespol* } & $\mathrm{Mg}$ & 17 & 6 & 16 & 465 & 64 & 0 \\
\hline & GJ & 138 & 68 & 130 & 6464 & 890 & 0 \\
\hline \multirow{2}{*}{ Biała Podlaska } & $\mathrm{Mg}$ & 4312 & 1560 & 154 & 29224 & 1851 & 15758 \\
\hline & GJ & 34927 & 17628 & 1247 & 406214 & 25729 & 222188 \\
\hline \multirow{2}{*}{ Drelów } & $\mathrm{Mg}$ & 4037 & 1461 & 85 & 13273 & 1971 & 6599 \\
\hline & GJ & 32700 & 16509 & 689 & 184495 & 27397 & 93046 \\
\hline \multirow{2}{*}{ Janów Podlaski } & $\mathrm{Mg}$ & 1135 & 411 & 82 & 12589 & 968 & 3143 \\
\hline & GJ & 9194 & 4644 & 664 & 174987 & 13455 & 44316 \\
\hline \multirow{2}{*}{ Kodeń } & $\mathrm{Mg}$ & 2162 & 782 & 80 & 7859 & 824 & 7896 \\
\hline & GJ & 17512 & 8837 & 648 & 109240 & 11454 & 111334 \\
\hline \multirow{2}{*}{ Konstantynów } & $\mathrm{Mg}$ & 1047 & 379 & 110 & 11966 & 207 & 1702 \\
\hline & GJ & 8481 & 4283 & 891 & 166327 & 2877 & 23998 \\
\hline \multirow{2}{*}{ Leśna Podlaska } & $\mathrm{Mg}$ & 754 & 273 & 50 & 12541 & 496 & 5282 \\
\hline & GJ & 6107 & 3085 & 405 & 174320 & 6894 & 74476 \\
\hline \multirow{2}{*}{ Łomazy } & $\mathrm{Mg}$ & 2517 & 911 & 104 & 20007 & 1183 & 13718 \\
\hline & GJ & 20388 & 10294 & 842 & 278097 & 16444 & 193424 \\
\hline \multirow{2}{*}{ Międzyrzec Podlaski } & $\mathrm{Mg}$ & 3378 & 1222 & 107 & 29944 & 1355 & 11824 \\
\hline & GJ & 27362 & 13809 & 867 & 416222 & 18835 & 166718 \\
\hline \multirow{2}{*}{ Piszczac } & $\mathrm{Mg}$ & 2500 & 905 & 65 & 17992 & 897 & 8835 \\
\hline & GJ & 20250 & 10227 & 527 & 250089 & 12468 & 124574 \\
\hline \multirow{2}{*}{ Rokitno } & $\mathrm{Mg}$ & 2229 & 807 & 59 & 7526 & 485 & 4994 \\
\hline & GJ & 18055 & 9119 & 478 & 104611 & 6742 & 70415 \\
\hline \multirow{2}{*}{ Rossosz } & $\mathrm{Mg}$ & 1051 & 380 & 27 & 8087 & 508 & 2483 \\
\hline & GJ & 8513 & 4294 & 219 & 112409 & 7061 & 35010 \\
\hline \multirow{2}{*}{ Sławatycze } & $\mathrm{Mg}$ & 275 & 100 & 87 & 7039 & 602 & 3455 \\
\hline & GJ & 2228 & 1130 & 705 & 97842 & 8368 & 48716 \\
\hline \multirow{2}{*}{ Sosnówka } & $\mathrm{Mg}$ & 1887 & 683 & 67 & 14649 & 1080 & 5747 \\
\hline & GJ & 15285 & 7718 & 543 & 203621 & 15012 & 81033 \\
\hline \multirow{2}{*}{ Terespol } & $\mathrm{Mg}$ & 1079 & 391 & 87 & 4619 & 1156 & 3302 \\
\hline & GJ & 8740 & 4418 & 705 & 64204 & 16068 & 46558 \\
\hline \multirow{2}{*}{ Tuczna } & $\mathrm{Mg}$ & 2313 & 837 & 61 & 19021 & 1116 & 7728 \\
\hline & GJ & 18735 & 9458 & 494 & 264392 & 15512 & 108965 \\
\hline \multirow{2}{*}{ Wisznice } & $\mathrm{Mg}$ & 1590 & 575 & 147 & 15069 & 1466 & 5901 \\
\hline & GJ & 12879 & 6498 & 1191 & 209459 & 20377 & 83204 \\
\hline 7 & $\mathrm{Mg}$ & 2485 & 899 & 77 & 9702 & 737 & 5227 \\
\hline Zalesie & GJ & 20129 & 10159 & 624 & 134858 & 10244 & 73701 \\
\hline Biała Podlaska & $\mathrm{Mg}$ & 34853 & 12610 & 1482 & 243501 & 17096 & 113595 \\
\hline County & GJ & 282309 & 142493 & 12004 & 3384664 & 237634 & 1601690 \\
\hline
\end{tabular}

*urban commune

wood in processing plants is used for the heating needs of these plants. Besides, waste is a raw material for the production of chipboard. Part of the raw material in the processing process is subjected to chemical substances and is thus useless for further energy purposes. Sawdust, which is used for the production of briquettes and pellets, is an important raw material generated during sawmill processing. Two plants are producing this type of solid fuel in the county [11].

\subsubsection{Waste wood resources from orchards, woodlots and roadsides}

Woodlots are productive and protective clusters of trees and shrubs outside the forests. They occur along communication routes and watercourses, as well as among agricultural crops, next to houses and outbuildings. To ensure road safety, constant care of roadside trees is necessary. Waste wood from fruit growing arises during the liquidation of old plantations and annual sanitary cuts (trees infected with diseases, pests, broken trees). Liquidation of the old orchard occurs on average 25 years after planting trees, and natural defects account for an average of $2 \%$ of the forest stand annually.

The estimated amount of waste wood from cleanouts, sanitary and renovation cuts, and roadside trees in Biała Podlaska County, obtained as a result of calculations, is about $1,500 \mathrm{Mg}$ per year and energy value of over 12,000 GJ (Table 1). In practice, wood from branches,

\footnotetext{
Corresponding author: alina.jusko@up.lublin.pl
} 
cleanouts and refurbishment cuts is used by households as a raw material for burning in boilers. Part of this resource is burned directly in the field and has no energy use. Only large orchards are of interest to companies involved in obtaining biomass for power plants. Waste wood from the cleaning of roadside tree care is often shredded and left at the place of harvest for natural decomposition. For now, obtaining this type of wood can be troublesome, but the proper organization of work can bring benefits in the form of an energy resource that can meet the needs of, e.g., local boiler rooms.

\subsection{Straw and hay resources for energy purposes}

Cereal straw potential is considered to be the most considerable untapped energy potential in agriculture. Most often, this raw material is used for agricultural purposes, including litter, fodder, or plowed as fertilizer. Its surpluses can be a valuable raw material for energy production. The reason for the creation of surplus straw is the decreasing number of livestock, with a simultaneous increase in the share of cereals in the crop structure. The decrease in the number of cattle and sheep, as well as changes in the animal feeding system, were the reason for abandoning the use of part of the permanent grassland area (meadows and pastures) or mowing them without harvesting. A rational way to use these surpluses is to burn them in boilers adapted for compressed straw or to produce briquettes and pellets. This will reduce the burning of straw in the fields, which is an environmentally hazardous activity (currently prohibited in Poland) and will also provide the valuable raw material for the power industry.

In the first place, straw should cover the demand for animal production (litter and fodder) and maintain a balanced sheet of soil organic matter (fertilization by plowing). Agriculture has a high demand for straw, therefore, by estimating the amount of straw that can be used for energy purposes, its demand in agriculture was calculated based on head-count and structure of sown crops, according to the methodology [12].

Hay resources from unused meadows were also estimated. It has been assumed that in Poland, the average hay yield from meadows where particular care is not carried out is $4.5 \mathrm{Mg} \cdot \mathrm{ha}^{-1}$.

Analyzing the amount of straw technical potential in individual communes of the Biała Podlaska County, it was found that the largest occurs in the rural communes of Międzyrzec Podlaski and Biała Podlaska (about $30,000 \mathrm{Mg}$ per year). Significant straw resources (about $20,000 \mathrm{Mg}$ per year) can be obtained from the Łomazy and Tuczna communes (Table 1). The total potential of straw that can be used in the County is annually over 243,000 Mg. The potential of hay that can be used for energy purposes in the County is over $17,000 \mathrm{Mg}$ per year.

The management of surplus hay and straw for energy purposes would allow obtaining over 3,622,000 GJ of energy. In addition to the significant benefits of managing agricultural surplus biomass, one should take into account the difficulties arising from their acquisition. These resources are fragmented, in the case of hay, often difficult to access in wetlands, and the quality of these raw materials is very diverse and depends on the humidity and content of mineral impurities, which are ash and negatively affect the operation of power boilers [16].

\subsection{Plant biomass resources for energy purposes}

Renewable energy development strategies in Poland tend to reduce the use of biomass from forests in favor of agro-biomass. In addition to waste biomass from agriculture, energy crops may also be found in the consumption structure of this biomass. Such plantations are established on more deficient soils where it is difficult to obtain satisfactory crops for feed and food. Especially perennial species, such as, for example, fastgrowing grasses (Miscanthus giganteus, Miscanthus sacchariflorus, and Spartina pectinata) or Sida hermaphrodita are suitable for permanent planting. High-yielding varieties of Salix viminalis can be planted in excessively humid places due to high water requirements. Energy plantations are not very common in the Lublin Voivodeship. However, it is possible to approximate the potential of land and the biomass obtained from it, which will be an energy raw material.

$10 \%$ of their area was assumed to be a safe level of use of marginal land suitable for energy crops. According to this estimation, the total area of energy crops in the Biała Podlaska County may amount to about 12.2 thousand ha. The technical potential of biomass to obtain from these lands, with an assumed yield of 9.3 $\mathrm{Mg} / \mathrm{ha}$, is over 113,000 tonnes, and its energy value exceeds 1,601,000 GJ (Table 1).

\subsection{Total solid biomass potential in the Biała Podlaska County}

The calculated potential of solid biomass in the Biała Podlaska County is differential in Communes (Fig. 1) and amounts over $423,000 \mathrm{Mg}$ per year, whose energy value is 5,670,000 MJ (Fig. 2). Agricultural waste biomass in the form of surplus straw for energy purposes has the largest share in this potential (59.69\%). An important source of solid biomass in the County may be the biomass of perennial energy crops (28.24\%), grown on marginal lands. This potential is theoretical, because plantations of perennial energy plants in the County, according to information from commune offices, occupy a total area of only 32 ha. The establishment of these plantations depends on the emergence of a real biomass market and the profitability of its production. Wood biomass (from forests, wood processing, orchards, midfield, and roadside tree stands) accounts for $7.88 \%$ of the total energy potential of the County. However, in fact, wood in various forms is the most-used biomass raw material. 


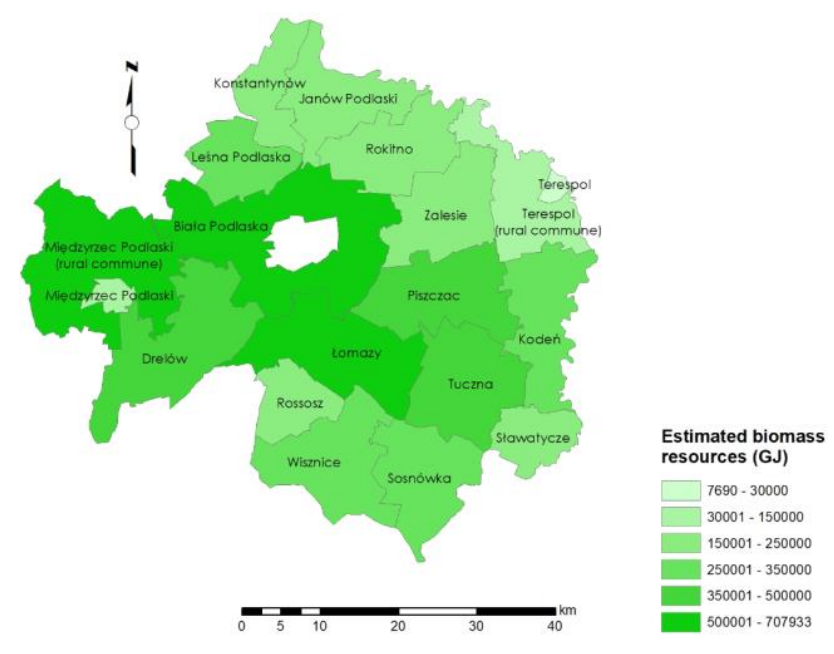

Fig. 1. Estimated biomass resources (GJ) in communes of Biała Podlaska County.

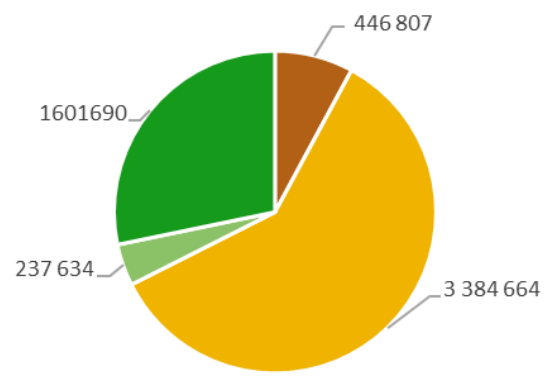

- Wood | Straw " Hay - Perennial energy crops

Fig. 2. Potential of energy (GJ) in the Biała Podlaska County.

\section{Conclusions}

1. An initial estimate of the potential of solid biomass, which can be obtained in the Biała Podlaska County (Poland), for energy purposes indicates that it amounts to about 423,000 Mg per year. The most energy can be obtained from crops (mainly straw - about $59.69 \%$ of the total biomass potential in the county), and then from plantations that could be established on poor quality agricultural land.

2. It is estimated that over 5.67 million GJ of energy stored in available solid biomass resources can be obtained annually in the Biała Podlaska County without compromising the food security of the region or country. 3 . Until the spread of energy crops, solid biomass from forests is the basic raw material for energy.

4. The estimated biomass energy potential gives a great understanding of the problem on a county scale. An indication of the biomass potential is essential because of the low unit weight, increasing transport costs. The most rational solution is to use biomass on a local scale, e.g., for heating communal buildings, individual residential buildings, or local boiler rooms.

\section{Acknowledgements}

Publication is funded by the Polish National Agency for Academic Exchange under the International Academic Partnerships Programme from the project „Organization of the 9th International Scientific and Technical Conference entitled Environmental Engineering, Photogrammetry, Geoinformatics - Modern Technologies and Development Perspectives".

\section{References}

1. Statistics Poland. www.stat.gov.pl

2. R. Szczerbowski, D. Kornobis, Energy Policy Journal 22 (3), 5-18 (2019) doi:10.33223/epj/111757

3. B. Gradziuk, P. Gradziuk, Barometr Regionalny. Analizy i Prognozy 3 (41), 153-159 (2015)

4. J. Studencka, Economics and Environment 4 (55), 112-123 (2015)

5. W. Czekała, S. Bartnikowska, J. Dach, D. Janczak, A. Smurzyńska, K. Kozłowski, A. Bugała, A. Lewicki, M. Cieślik, D. Typańska, J. Mazurkiewicz, Energy 159, 1118-1122 doi:10.1016/j.energy.2018.06.090

6. F. Woch, J. Hernik, E. Sankowski, P. Pióro, M. Pazdan, T. Noszczyk, Polish Journal of Environmental Studies, 29 (1), 885-891 (2020)

7. M.J. Stolarski, M. Krzyżaniak, S. Szczukowski, J. Tworkowski, A. Bieniek, Polish Journal of Environmental Studies, 23 (5), 1727-1739 (2014)

8. P. Pochwatka, A. Kowalczyk-Juśko, A. Mazur, D. Janczak, J. Pulka, J. Dach, 4th Int. Conf. Green Energy Appl., IEEE; 130-133 (2020) doi.org/10.1109/ICGEA49367.2020.239705.

9. G. Maj, W. Piekarski, A. Kowalczyk-Juśko, A. Łukaszczyk, Przem Chem 93 (5), $732-736$ (2014) doi:dx.medra.org/10.12916/przemchem.2014.732

10. W. Czekała, J. Dach, R. Dong, D. Janczak, K. Malińska, K. Jóźwiakowski, A. Smurzyńska, M. Cieślik, Biosystems Engineering, 160, 25-29 (2017) doi:10.1016/j.biosystemseng.2017.05.003.

11. A. Listosz, A. Kowalczyk-Juśko, A. Mazur, K. Jóźwiakowski, M. Gizińska-Górna, A. Pytka, M. Marzec, Water-Environment-Rural Areas 4 (60), 8193 (2017)

12. A. Kowalczyk-Juśko, Scientific Journal of Warsaw University of Life Sciences-SGGW, Economics and Organization Agri-Food Sector, 85 103-116 (2010)

13. P. Paschalis-Jakubowicz, Sylwan 162, 688 (2018)

14. J. Buczek, B. Kryńska, Innovations in plant technologies as a basis for shaping agricultural production space by local government (Rzeszów University, 1-8, 2007)

15. F. Woch, J. Hernik, P. Wyrozumska, B. Czesak, Polish Journal of Environmental Studies 24 (1), 355358 (2015)

16. A. Kowalczyk-Juśko, Journal of Ecological $\begin{array}{lllll}\text { Engineering } 18 \quad(6), & 200-204 & \text { (2017) doi: }\end{array}$ $10.12911 / 22998993 / 7687$ 